\title{
Etnisitas, teologi, dan musik dalam nyanyian gereja: sketsa awal studi etnoteomusikologi nyanyian Gereja Protestan Maluku
}

\author{
Dewi Tika Lestari \\ Institut Agama Kristen Negeri Ambon, Maluku \\ dewitikalestari85@gmail.com
}

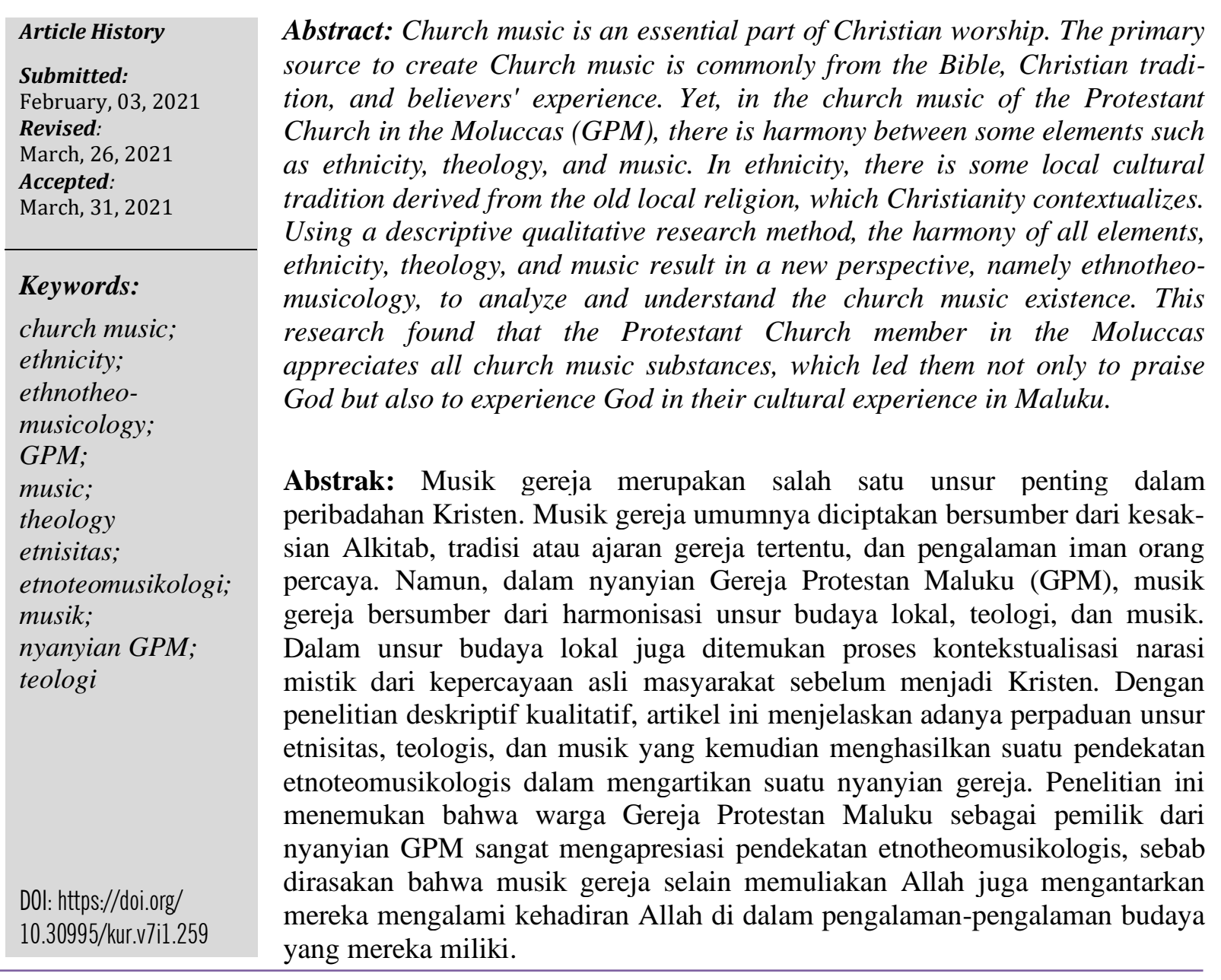

\section{Pendahuluan}

Musik adalah salah satu unsur penting di dalam tradisi peribadahan Kristen. Namun, tidak semua musik dapat menjadi musik yang fungsional di dalam peribadahan Kristen. Karld Edmund Pier dan Paul Widyawan membuat pembedaan antara musik profan dan sakral. Distingsi ini mempunyai masalah tersendiri yang membedakan ada dunia di mana Tuhan hadir (sacral), dan ada dunia di mana Tuhan tidak hadir (profan). Pembedaan seperti ini memang dipengaruhi kuat oleh rasionalisme Barat abad XVIII, namun tidak cocok dengan alam pemikiran Timur di mana hanya terdapat satu dunia. Misalnya, di Pura Bali tari dan gamelan Bali yang riuh pun ada tempatnya, mengadakan musyawarah dan makan di masjid 
tidak bertentangan dengan tempat suci, mengadakan ibadah di rumah keluarga tidaklah bermasalah. Ada lagu yang tujuannya hiburan, dan ada lagu yang tujuannya permohonan kepada Tuhan. Menurut Pier dan Widyawan, perbedaan ini terletak dalam sikap orang yang menciptakan dan yang menyanyikan lagu tersebut, selain juga di dalam syairnya. Namun, tidak ada tangga nada, ritme, harmoni, alat pengiring, bahasa atau tempat yang dikhususkan untuk lagu sakral atau lagu profan. ${ }^{1}$

Kenneth W. Osbeck menggunakan ungkapan sacred music untuk menegaskan peran musik dengan asosiasi khusus dari pengalaman penyembahan manusia kepada sebuah kuasa tertinggi (a supreme power) atau yang dikenal dalam Kekristenan sebagai penyembahan kepada Allah. Osbeck menjelaskan bahwa sejarah perkembangan musik sakral yang terdapat dalam Alkitab telah dimulai pengunaannya dari bangsa Mesir, Israel, Yunani-Romawi, kemudian oleh umat Yahudi dan umat Kristen di masa Yesus. Kata musik, para pemusik, instrumen musik, himne, lagu, singer, dan nyanyian disebutkan sebanyak 575 kali di dalam Alkitab. Penggunaan kata-kata dan ekspresi yang berkaitan dengan musik ditemukan dalam 44 Kitab dari 66 jumlah kitab kanonik umat Kristen. ${ }^{2}$ Musik sakral di dalam lintasan sejarahnya memainkan peranan penting di mana melalui musik, manusia mengungkapkan imannya kepada Allah (faithfulness to God), lebih daripada memuliakan diri sendiri (selfglory). ${ }^{3}$ Agustinus C.W. Gaspersz, yang mengutip Femi Adejeji, menyatakan bahwa musik gereja adalah teks Kristen, yang bersumber dari Alkitab. Musik gereja adalah musik dengan suara teologis. Gaspersz menegaskan bahwa nyanyian gereja yang digunakan oleh Gereja Protestan Maluku (GPM) untuk perayaan ibadah seluruhnya mengandung pesan teologis sesuai dengan ajaran Kristen. ${ }^{4}$

Persoalan mendasar muncul di dalam pandangan bahwa musik gereja adalah musik sakral yang berbeda dengan musik profan. Atau seperti yang diungkapan oleh Gaspersz, yang mengutip Femi Adejeji bahwa musik gereja adalah musik teologis yang hanya bersumber dari Alkitab dan ajaran Kristen. Berbeda dengan pandangan tersebut, dalam buku Nyanyian Gereja Protestan Maluku (Nyanyian GPM), ditemukan bahwa nyanyian gereja tidak hanya bersumber dari Alkitab dan ajaran teologis Kristen, tetapi juga ungkapan-ungkapan dalam konteks budaya Maluku dari berbagai daerah. Tidak sebatas pada teksnya, tetapi unsur musik lain seperti melodi, ritme, dan harmoninya menggunakan unsur musik etnik di Maluku. Apakah perpaduan unsur budaya, teologi, dan musik seperti pada nyanyian GPM masih dapat disebut sebagai musik gereja?

Triyono Bramantyo yang melakukan penelitian disertasi mengenai diseminasi musik Barat di Timur, menjelaskan bahwa para misionaris dari Belanda dan Portugis dalam melakukan pemberitaan Injil di Indonesia, terutama di wilayah Maluku, justru menggunakan tradisi dan budaya masyarakat Maluku yang menyukai musik untuk bermisi. Musik sakral menjadi suatu perpaduan antara tradisi dan budaya masyarakat Maluku dengan musik di

\footnotetext{
${ }^{1}$ Karl Edmund Prier and Paul Widyawan, Roda Musik Liturgi : Panduan Untuk Para Petugas Musik Liturgi (Yogyakarta: Pusat Musik Liturgi, 2011), 19.

${ }^{2}$ Kenneth W Osbeck, The Ministry of Music (Grand Rapids: Kregel Publication, 2010), 17-18.

${ }^{3}$ Ibid., 32.

${ }^{4}$ Agustinus S.W. Gaspersz, Sejarah Penyebaran Nyanyian Gereja Oleh Misionaris Belanda Di Maluku (Yogyakarta: TICI Publication, 2013), 13.
} 
dalam tradisi dan ajaran gereja. Hal inilah yang menyebabkan penyebaran Kekristenan di Maluku dapat berhasil dibandingkan dengan wilayah lain di nusantara. ${ }^{5}$

Lebih lanjut, Bramantyo menjelaskan bahwa Xaverius dan para misionaris Jesuit lainnya menyadari apa yang benar-benar dilakukan untuk menarik umat Kristen pribumi, yakni bukan hanya lewat ajarannya saja, melainkan juga melalui berbagai macam upacara dan terutama melalui musik ritual. Hal ini berpaut erat dengan kecintaan masyarakat Maluku pada musik. Ketika musik ritual gereja dengan kebudayaan masyarakat berpaut, maka di rumahrumah para wanita dan anak-anak sepanjang waktu bernyanyi ungkapan pengakuan iman (creed), doa bapa kami (Pater noster), dan karya-karya kerahiman lainnya. Orang-orang lelaki terus bernyanyi di hutan dan di laut lagu-lagu budaya mereka, juga lagu-lagu liturgis yang telah dikontekstualisasikan di dalam tradisi masyarakat pribumi. ${ }^{6}$

Musik gereja di Maluku tidak hanya merupakan musik ritual yang berisikan berbagai doktrin atau ajaran, pengakuan, dan tradisi-tradisi liturgis gereja. Lebih dari itu, musik gereja Maluku merupakan perpaduan dari unsur-unsur budaya di Maluku, ajaran atau pandangan teologis, dan unsur musik. Di dalam penelitian ini, musik gereja Maluku yang dimaksudkan adalah musik yang secara kanonik telah ditetapkan dalam Sidang Sinode GPM ke-36, sebagai buku nyanyian Gereja Protestan Maluku (Nyanyian GPM). Buku nyanyian GPM disusun oleh Tim Musik dan Liturgi GPM yang kemudian dibahas dan disahkan di dalam persidangan Sinode GPM ke-36 Tahun 2010, lalu digunakan oleh jemaat-jemaat baik yang merupakan anggota GPM, tetapi juga oleh warga jemaat lainnya.

Di dalam nyanyian GPM, ditemukan perpaduan harmonis antara unsur-unsur budaya Maluku dengan ajaran dan pandangan teologis yang terajut di dalam unsur-unsur musik liturgis dari setiap lagu. Unsur-unsur budaya itu dapat berupa baik tata nilai dan pandangan hidup, ungkapan leksionaris budaya Maluku seperti pela-gandong, basudara, Ain ni Ain, basudara, upu lanite, dan berbagai bahasa yang termuat dalam teks lagu, juga terekspresikan di dalam nada, melodi, ritme musikal. Perpaduan unsur-unsur budaya, teologis dan musik memiliki peranan dan fungsi, tidak sebatas untuk menjadi suatu ekpresi memuliakan Tuhan di dalam peribadahan, tetapi juga melekat fungsi membangun identitas budaya sebagai masyarakat Maluku, secara khusus yang beragama Kristen. Demikian, dalam nyanyian GPM dapat ditemukan unsur yang membentuknya, yakni etnisitas Maluku, ajaran teologis, dan musik, yang diperkenalkan dalam tulisan ini sebagai etnoteomusikologis.

Studi etnoteomusikologis merupakan sebuah pendekatan yang baru dikembangkan dalam tulisan ini, berbeda dari berbagai pendekatan kajian musik (musicology) sebelumnya seperti etnomusikologi dan teomusikologi. Pendekatan etnoteomusikologis akan dibahas pada bagian inti dari kajian ini. Pilihan untuk mengembangkan pendekatan studi ini disebabkan dua hal pokok. Pertama, konteks permahasalahan yang dikaji menentukan pendekatan yang digunakan. Dalam studi ini, konteks seperti yang sudah dijelaskan adalah adanya fenomena musik gereja dalam nyanyian GPM yang dibentuk dari perpaduan unsur-unsur etnik Maluku, pandangan teologis, dan musik. Itulah sebabnya, pendekatan etnoteomusikologis - yang

${ }^{5}$ Triyono Bramantyo, Desiminasi Musik Barat Di Timur (Yogyakarta: Yayasan Untuk Indonesia, 2004), 47.

\footnotetext{
${ }^{6}$ Ibid., 48.
} 
dikreasikan di sini sebagai sebuah sketsa awal, merupakan sebuah pendekatan yang relevan mengkaji ketiga unsur tersebut. Kedua, berangkat dari konteks permasalahan, yakni adanya tiga unsur utama yang membentuk sebuah komposisi musik gereja dalam nyanyian GPM, maka tentunya pendekatan lain seperti etnomusikologis, atau teomusikologis, atau musikologis sendiri - yang lebih menekankan pada dua unsur utama (etno+musik, dan teologi+musik) atau satu unsur utama (musik), memiliki keterbatasan pandangan (blind spot) untuk mengulas tiga unsur yang terdapat dalam konteks permasalahan yang dikaji. Oleh karena itu, saya berpendapat bahwa komposisi musik gereja di dalam nyanyian GPM dapat dijelaskan maknanya dan fungsinya dengan menggunakan pendekatan etnoteomosikologis, yang merelasikan secara analitis dan sistematis unsur-unsur yang terlibat, yakni etnik, teologi, dan musik. Uraian ini sekaligus menegaskan bahwa sebuah karya musik gereja di dalam bentuk sebuah nyanyian gereja (yang terdiri dari teks= syair; dan lagu = melodi, irama, tempo, ritme, dan dinamika) tidak hanya dapat dikomposisi bersumber dari unsur teologis dan musik, tetapi juga dari unsur-unsur etnik dari suatu jemaat lokal di mana musik itu dikreasikan.

Disadari sungguh bahwa pendekatan ini merupakan sesuatu yang baru diperkenalkan dalam analisis musik gereja, maka studi ini adalah sebuah sketsa awal. Sebagai sebuah sketsa, analisis terhadap karya seni (musik) dalam nyanyian GPM masih secara generalis, dan analisis partikularnya dilakukan dengan menggunakan salah satu contoh dari nyanyian GPM. Analisis ketiga unsur dalam nyanyian GPM dilakukan baik melalui interpretasi teks atau syair, dan unsur lagu lain seperti irama, tempo, dinamika, maupun dalam deskripsi analitis terhadap persepsi informan, yakni para pelaku seni, pendeta, dan warga gereja yang menghasilkan dan menggunakan nyanyian GPM.

\section{Metode Penelitian}

Kajian ini menggunakan metode yang disebutkan oleh Susan Finley sebagai metode penelitian kualitatif berbasis seni. Penelitian kualitatif berbasis seni merupakan satu genre metodologis dan teoritis di antara sekian banyak bentuk penelitian kualitatif yang baru. Metode penelitian ini merupakan suatu upaya sistematis dan analitis untuk menggali makna sekaligus menghargai kontribusi dari sebuah karya seni (seperti tari, musik, film, lukis, dan seterusnya) dalam memahami dan membangun kehidupan suatu komunitas. Penelitian jenis ini melakukan interpretasi terhadap karya-karya seni, sekaligus menemukan atau mengreasikan makna yang terkandung di dalam karya seni bagi kehidupan komunitas lokal pemilik karya seni itu. ${ }^{7}$ Dalam kaitan itu, unit amatan yang diteliti adalah sebuah karya seni (musik gereja) dalam bentuk nyanyian GPM yang dihasilkan dan digunakan oleh komunitas warga Gereja Protestan Maluku. Selanjutnya, unit analisisnya adalah perpaduan unsur-unsur etnik, teologi, dan musik yang terdapat di dalam nyanyian GPM. Selain interpretasi terhadap unsurunsur tersebut, analisis deskriptif terhadap pandangan komunitas yang menghasilkan dan menggunakan nyanyian GPM, seperti para musisi, pendeta, dan warga jemaat GPM. Analisis

\footnotetext{
${ }^{7}$ Susan Finley, "Penelitian Berbasis Seni: Mementaskan Pedagogi Revolusioner," in The Sage of Qualitative Research 2, ed. Norman K Denzin and Yvnonna S Linncoln, 3rd ed. (Yogyakarta: Pustaka Pelajar, 2011), 44-45.
} 
ini bertujuan untuk menemukan atau menggali makna di balik perpaduan unsur-unsur etnik, teologi, dan musik di dalam nyanyian GPM.

\section{Pembahasan}

\section{Memahami Etnoteomusikologi}

Penelitian ini menganalisis nyanyian GPM di dalam pendekatan analisis. Pendekatan ini adalah suatu imaginasi kreatif yang menghubungkan pakem etnomusikologi dan teomusikologi yang telah ada. Sebelumnya, perlu dipahami apa yang dimaksud dengan analisis etnomusikologi dan teomusikologis. Prinsip analisis etnomusikologi menegaskan bahwa musik harus dipahami di dalam konteks sosial, kultural, dan etnisitas masyarakat pemilik musik. ${ }^{8}$ Menurut Shin Nakagawa, objek atau sasaran penelitian etnomusikologi adalah musik etnik, yang berpaut dengan keberadaan musik di dalam etnik masyarakat tertentu, seperti musik etnik Jawa, musik etnik Bali, dan seterusnya. Lebih daripada itu, Nakagawa memperluas horizon penelitian etnomusikologi kepada semua musik yang terkait dengan mentalitas, kebudayaan, dan lingkungan tertentu, yang berada di dunia. ${ }^{9}$ Menurut Sri Hastanto, prinsip etnomusikologi dalam penelitian musik menegaskan bahwa mengolah dan memaknai data selalu menggunakan kacamata budaya dan kebiasaan dalam masyarakat pemilik musik tersebut. Data yang dimaksud adalah segala sesuatu, baik itu benda fisik, peristiwa musikal, perasaan dan pandangan manusia yang mempunyai sangkut paut langsung atau tidak dengan rasa musikal pada sebuah karya musik. ${ }^{10}$ Saya menyebutnya dengan konsep musik lokal atau musik dari dan berada di dalam suatu masyarakat lokal, yang berbeda dari konteks regional dan global. Di dalam masyarakat lokal itu pun bisa terjadi perpaduan etnik atau konteks-konteks yang lebih partikular yang mempengaruhi kreativitas dan keberadaan suatu musik. ${ }^{11}$

Selanjutnya, pendekatan teomusikologi menekankan rajutan korelasional unsur musik dengan unsur teologis dalam mengomunikasikan pesan-pesan teologis secara musikalitas. ${ }^{12}$ Maeve Louise Heaney lebih jauh melihat relasi musik dan teologi di dalam sebuah paradigma metodologi. Heaney mendeskripsikannya paling kurang dalam tiga preposisi. Pertama, musik adalah bagian dari teologi aestetik, di mana musik memainkan peran penting di dalam metode berteologi. Baik teolog maupun composer dapat menggunakan peran musik untuk mengungkapkan pemikiran dan pesan teologis. Heaney menyebutkan:

We find theologians who have made explicit the role of music in their thought, and those who seem to have avoided doing so; composers who consciously seek to express Christian doctrine or thought, and those who perhaps did not have that intention but whose music has nonetheless been taken up as theologically significant. ${ }^{13}$

\footnotetext{
${ }^{8}$ Dewi Tika Lestari, “Membangun Harmoni Sosial Melalui Musik Dalam Ekspresi Budaya Orang Basudara Di Maluku," Panggung (2020).

${ }^{9}$ Shin Nakagawa, Musik Dan Kosmos: Sebuah Pengantar Etnomusikologis (Jakarta: Yayasan Obor Indonesia, 2000), 4.

${ }^{10}$ Sri Hastanto, Konsep Pathet Dalam Karawitan Jawa (Surakarta: Program Pascasarjana dan ISI Press Surakarta, 2009), 3.

${ }^{11}$ Dewi Tika Lestari, "Religious Conflict Transformation through Collective Memory and the Role of Local Music," 2019.

12 Dewi Tika Lestari and Yohanes Parihala, “Teologi, Musik, Dan Perdamaian: Visi Teologi Lukas 12: 51-53 Dan Analisis Musik Ode Buat Maluku," DUNAMIS: Jurnal Teologi dan Pendidikan Kristiani (2020).

${ }^{13}$ Maeve Louise Heaney, "Music and Theological Method: A Lonerganian Approach," Theological Studies 77, no. 3 (September 2016): 680, http://tsj.sagepub.com/ (Subscriber access).
} 
Kedua, menurut Heaney, musik tidak sekedar berperan sebagai media (aestetik) merefleksikan pemikiran teologis, melainkan menjadi sumber berteologi. Ia menyebutkan: "I am speaking not only of reflections on music as a topic, but the actual presence of music in and as a source for theology, and even as a form of theological reflection." 14

Bertolak dari dua pendekatan di atas, etnomusikologis dan theomusikologis, studi ini merambah suatu pendekatan baru, yang menghubungkan secara paradigmatik dan aestetik interelasional unsur etnik, musik, dan teologi, yang disebut etnotheomusikologis. Secara paradigmatik, masing-masing unsur mempunyai paradigma metodologis sebagai sebuah disiplin keilmuan (etnologi, musikologi, dan teologi), yang dapat menyumbangkan suatu kerangka analisis mengenai hubungan musik, etnisitas dan teologi. Secara aestetik, eksplorasi musik dapat bersumber dari unsur-unsur etnik dan teologi, atau sebaliknya, refleksi teologi atau etnisitas dapat dilakukan melalui musik. Di dalam ekspresi suatu karya musik, ketiga unsur ini bisa sekaligus termuat, dan dapat diungkapkan secara bersama. Dalam penelitian ini, potensi korelasional antara unsur etnik, musik dan teologi dapat ditemukan di dalam nyanyian GPM.

Dalam penelitian disertasinya mengenai kontekstualisasi musik, Tamaela menyebutkan:

Dalam kontekstualisasi musik dan liturgi di Gereja Prostestan Maluku, musik etnik Maluku dan teologi merupakan dua unsur yang terpisah, namun di dalam prakteknya, kedua unsur ini dapat dirajut bersama sehingga menghasilkan keindahan estetis di dalam musik itu sendiri, sekaligus sebagai suatu akta liturgis. Dengannya, musik juga dilihat sebagai anugerah Allah bagi kehidupan. ${ }^{15}$

Adanya korelasional musik, etnisitas dan teologi dalam Nyanyian Jemaat GPM juga dipengaruhi oleh konteks masyarakat Maluku yang memiliki habitus kultural dalam menyanyi. Oleh karena itu, perkembangan musik gereja dalam Nyanyian GPM berkorelasi dengan warna musik lokal Maluku. Analisis ini selanjutnya memaparkan mengenai konsep musik lokal Maluku, dan analisis Nyanyian GPM untuk mengungkap korelasi unsur-unsur musik, budaya, dan teologi.

\section{Sintesis Kreatif Musik Lokal Maluku}

Deskripsi mengenai makna musik lokal Maluku didasarkan pada beberapa persepsi informan, yang telah penulis kumpulkan dalam melakukan beberapa penelitian sebelumnya, dan juga dari sumber referensi yang digunakan. Masyarakat Maluku memahami diri mereka sebagai masyarakat bermusik sejak dahulu hingga saat ini. Hal ini menjadi salah satu alasan kuat Pemerintah Kota Ambon menetapkan dan mendeklarasikan kota Ambon sebagai the city of music. Walikota Ambon, Richard Lohenapessy ketika diwawancarai, menegaskan bahwa penamaan Ambon sebagai kota musik semata-mata ingin menghidupkan kembali ingatan kolektif semua masyarakat sekaligus menggemakan kepada semua orang mengenai identitas masyarakat Maluku sebagai masyarakat bermusik. Menurut Lohenapessy, musik telah mendarah-daging dan menjadi jiwa yang menghidupi seluruh gerak aktivitas sosial dan kebudayaan masyarakat Maluku. Demikian, Lohenapessy mengatakan:

\footnotetext{
${ }^{14}$ Ibid., 682.

${ }^{15}$ Christian Izaac Tamaela, "Contextualization of Music and Liturgy in the Moluccan Church" (Vrije Universiteit, Amsterdam, 2015), 71.
} 
Sejak dahulu, para leluhur dalam mengkomunikasikan sesuatu yang sangat penting berkaitan dengan relasi antar sesama dan dengan Tuhan, selalu mengunakan nyanyian kapata. Hingga saat ini, di mana saja, orang Maluku melakukan aktivitas, dari jalan raya sampai ke perkantoran, dari tengah laut sampai ke hutan dan pegunungan, selalu terdengar suara musik dan nyanyian. Masyarakat Maluku itu adalah masyarakat bermusik dari dolo sampe oras ini - dari dulu sampai sekarang ini. Musik adalah semacam jiwa atau nafas yang menghidupkan seluruh gerak aktivitas masyarakat. ${ }^{16}$

Kebiasaan bermusik dari masyarakat Maluku telah dihidupi dan dikembangkan sejak dahulu hingga saat ini. Segala peristiwa atau kenyataan hidup selalu diungkapkan dengan berbagai lagu, seperti ada lagu peperangan, perpindahan penduduk, persaudaraan, perjuangan dan kerja, hingga lagu-lagu ratapan. Budaya musik masyarakat Maluku melekat dengan kehidupan setiap hari. Di desa-desa misalnya, hingga saat ini untuk memanggil seseorang atau menyampaikan suatu berita, selalu menggunakan alat-alat musik tradisi, seperti tolengtoleng, tifa, kleper, atau dengan suara nyanyian. Selain itu, sejak dahulu alam Maluku menjadi salah satu medium mengekspresikan jiwa bermusik masyarakat. Misalnya, pola ritme dari lambaian daun sagu atau rumbia, dan deburan ombak di laut, serta keindahan alam menyajikan kepada masyarakat Maluku suatu pola bermusik yang sekaligus membentuk jati diri masyarakat yang suka bermusik. Musik telah menjadi bagian integral dalam budaya dan hidup keseharian masyarakat Maluku. ${ }^{17}$ Kendati demikian, Jip Lensink, yang mengutip gagasan Margaret Kartomi, menyebutkan bahwa musik lokal Maluku merupakan suatu mikro-musik, yang dihasilkan dari suatu sintesis kreatif antara tradisi lokal dan pengaruh musik dari luar. ${ }^{18}$

Sintesis kreatif musik lokal daerah Maluku dapat dibagi ke dalam dua bagian besar, yaitu musik tradisional Maluku dan musik tradisional di Maluku. Pengelompokkan ini didasarkan pada sejarah dan wujud atau ciri dari suatu karya musik yang dikreasikan, diapresiasi, dan dinikmati oleh masyarakat Maluku sebagai pemilik musik tersebut. Musik tradisional Maluku adalah musik asli yang lahir dan berkembang di daerah Maluku atau disebut dengan musik lokal Maluku. Musik tradisional adalah musik yang belum dipengaruhi oleh unsur-unsur musik dari luar daerah Maluku.

Musik tradisional Maluku mencakup musik instrumen dan musik vokal. Kedua bentuk musik tradisional Maluku ini berasal dari pengembangan bunyi-bunyian di alam Maluku. Bunyi-bunyian dari unsur alam tentunya masih sangat naturalistik, belum berangkat dari suatu produk teori musikal, tetapi memiliki sense musik yang bernilai dan dapat dinikmati oleh masyarakat pemiliknya. Musik tradisi ini dikreasikan bermula dari kebiasaan masyarakat membunyikan benda-benda di alam, seperti batu, kayu, bambu, kulit siput, dan sebagainya. Bunyi yang dipantulkan dari benda-benda alam ini menjadi instrumen pengiring suara nyanyian masyarakat.

Seiring dengan perkembangan masyarakat, benda-benda alam tersebut kemudian dikreasikan menjadi alat-alat musik tradisional Maluku dengan penataan bunyi sesuai dengan

\footnotetext{
${ }^{16}$ Lohenapessy (Walikota Ambon), Wawancara, 04-08-2018.

17 Dewi Tika Lestari, "Peran Musik Sebagai Salah Satu Media Perdamaian” (Institut Seni Indonesia (ISI) Surakarta, 2017).

18 Jip Lensink, “Traditional Tunes Transformed: Resonance and Dissonances Between Theology and Lived Religion in The Protestant Church on the Central Moluccas" (Utrecht University, n.d.), 23.
} 
selera seni dan rasa keindahan yang dimiliki masyarakat. Tamaela menyebutkan beberapa contoh musik instrument asli Maluku berdasarkan pembagiannya, yaitu: Idiophones terdiri dari Baner Kayu (wooden slit drum), toleng-toleng (bamboo gong), pong-pong (bamboo cylinder drum), akapeti atau totobuang kayu (wooden xylophone), takatak hatu (stone clapper), gring-gring kuli bia (shell chimes); alat musik membranophone yang terdiri dari tifa kayu dan tifa bulu; alat musik Chorrdophone terdiri dari plomplang bulu, klong, dan tingkoby, alat musik Aerophone terdiri dari tahuri bia, tahuri bulu, suling bamboo dan suling kelapa. ${ }^{19}$ Berkaitan dengan penataan bunyi, sejak zaman dahulu para leluhur Maluku telah mempunyai tangga nada tersendiri yang terdiri dari dua nada (ditonis), tiga nada (tritonis), empat nada (tetratonis: la-do-re-mi), dan lima nada (pentatonis: do-re-mi-sol-la). Tangga-tangga nada tersebut kecuali dwitonis, dapat ditemukan pada kapata-kapata.

Kapata merupakan nyanyian atau lagu asli Maluku. Tamaela menjelaskan bahwa kapata adalah tradisi menuturkan peristiwa dan sejarah masa lampau yang disampaikan secara setengah bernyanyi dan setengah berbicara. Kapata berasal dari kata Kapa, Pata dan Tita. Kapa berarti puncak gunung yang berbentuk tajam seperti jari telunjuk ke langit, Pata berarti keputusan yang tidak dapat berubah, dan Tita berarti ucapan atau sabda. Jadi, KapaPata- Tita bermakna ucapan yang tidak dapat berubah yang naik sebagai gunung berpuncak tombak tertuju kepada Sang Pencipta. Dengan kata lain, kapata adalah ungkapan yang berhubungan dengan pengalaman sejarah dan kepercayaan manusia Maluku yang dituturkan sambil bernyanyi kepada sesamanya dan kepada Sang Pencipta. ${ }^{20}$

Selain musik tradisional Maluku, terdapat pula musik tradisional di Maluku yang dipahami sebagai musik yang berasal dari budaya musik luar Maluku lalu kemudian masuk dan menyatu sebagai bagian dari tradisi dan budaya Maluku. Itu berarti musik-musik tersebut tidak berasal dari alam Maluku dan tidak dicipta atau dibuat oleh masyarakat Maluku. Masuknya musik-musik tradisional dari luar di Maluku berkaitan erat dengan kedatangan agama Islam di Maluku pada abad ke-15, kemudian bangsa Portugis sebagai penyebar agama Kristen Katolik pada abad ke-16, dan bangsa Belanda yang menyebarkan agama Kristen Protestan pada abad ke-17.

Instrumen musik tradisional yang dibawa masuk dari pengaruh kebudayaan Islam antara lain: rebana dan gambus, musik totobuang yang terbuat dari gong dengan bahan bakunya logam, filutu atau suling bambu vertikal, musik cikamomo yang terdiri dari delapan buah gong, saragi atau sebuah gong besar, gong Sembilan, tifa podo atau tifa dengan dua kepala, dabi-dabi. Di samping itu, bangsa Portugis dan Belanda mewariskan berbagai bentuk musik Barat, seperti alat-alat musik gitar, biola, ukulele, suling bambu, dan nyanyiannyanyian gerejawi seperti Mazmur, Tahlil, Dua Sahabat Lama. Pengaruh musik Barat juga terdapat dalam sistem tangga nada yang diwariskan, yaitu sistem tangga nada diatonik atau

${ }^{19}$ Christian Izaac Tamaela, "Contextualization of Music and Liturgy in the Moluccan Church," 40.

${ }^{20}$ Falantina Ery Latupapua et al., Kapata: Sastra Lisan Di Maluku (Ambon: Balai Pengkajian Nilai Budaya Provinsi Maluku dan Maluku Utara, 2012). 
heptatonik $^{21}$, yang masih berpengaruh hingga saat ini pada rasa musikal dan proses penciptaan lagu-lagu daerah Maluku, termasuk lagu-lagu di dalam Nyanyian Jemaat GPM.

\section{Etnoteomusikologis dalam Nyanyian GPM}

Nyanyian Gereja yang menjadi fokus analisis adalah Buku Nyanyian Jemaat GPM. Buku Nyanyian Jemaat GPM diadakan berdasarkan ketetapan Sidang ke-35 Sinode GPM Tahun 2005. Buku ini merupakan wujud Kerjasama GPM dengan Gereja Injili Maluku (GIM) di Belanda. Buku ini sampai selesai dalam bentuknya yang terakhir adalah karena kerja dari Tim Kerja Nyanyian Grejawi GPM. Dalam halaman akhir buku ini disebutkan Tim inti terdiri dari Monica Parera, Semuel Agustinus Toisuta, Esaf Mailoy, Christian Izaak Tamaela, Branckley E. Picanussa, August C.W. Gaspersz, Deetje Matulapelwa, Bartje Istia, Edgard J de Lima, Monike Hukubun, P.J. Ferdinandus, dan Johana Komul. Komposisi ini memperlihatkan bahwa anggota tim inti musik gerejawi adalah warga GPM baik yang berlatarbelakang musisi, teolog, dan akademisi serta pemerhati budaya Maluku. ${ }^{22}$

Dalam pengantar cetakan pertama buku ini oleh Badan Pekerja Harian Sinode GPM, ditegaskan bahwa buku nyanyian jemaat ini berisi lagu-lagu ciptaan dari warga gereja. Lirik dan melodi dari lagu-lagu yang terkumpul merupakan ekspresi iman umat dalam konteks budaya dan pergumulan sosial orang-orang percaya di propinsi Maluku dan Maluku Utara. Lagu-lagu ini merupakan upaya kontekstualisasi teologi di bidang musik. Hal ini juga ditegaskan dalam pengantar cetakan kedua buku ini oleh MPH Sinode Periode 2015-2020, bahwa Nyanyian Jemaat GPM merupakan kekayaan rohani GPM yang menghidupi syair dan melodinya sebagai ungkapan teologi gereja.

Buku Nyanyian Jemaat GPM berisikan 342 nyanyian untuk dipakai dalam ibadah, perkumpulan jemaat, rumah tangga, ataupun peristiwa-peristiwa gerejawi lainnya. Ada 79 pencipta lagu yang menyerahkan karyanya untuk dimuat dalam buku lagu ini. Mereka berasal dari hampir seluruh wilayah Maluku dengan latar belakang seni dan budaya yang berbeda.

Dalam penjelasan mengenai buku nyanyian jemaat, Tim menjelaskan bahwa buku ini telah memenuhi unsur kelayakan untuk digunakan sebagai nyanyiaan jemaat (hym) atau nyanyian persekutuan jemaat (Community Singing). Hal ini didukung oleh beberapa kriteria utama, yaitu karena mengandung unsur-unsur teologi, musik, bahasa dan kearifan budayanya yang telah dikaji dan diuji sedemikian rupa oleh Tim Inti maupun disetujui secara resmi oleh Sidang Sinode GPM. Lebih lanjut dijelaskan juga bahwa semua nyanyian dalam buku ini disajikan dengan cukup sederhana, seperti terlihat pada tingkahan lagu (melodic countour) dengan interval nada-nadanya (rhythmic pattern), dan biramanya (time signature), dan bentuk lagu (form), yang semuanya bisa dinyanyikan oleh jemaat.

Faktor kesederhanaan (simplicity) adalah salah satu sifat utama dari sebuah nyanyian jemaat yang baik dan berkualitas. Kesederhanaan bukan berarti bahwa semua nyanyiaan ini tidak berkualitas, tetapi merupakan nyanyian-nyanyian yang mudah diresapi, dinyanyikan, diekspresikan, dan dihayati oleh setiap warga jemaat.

${ }^{21}$ Musik Barat menngunakan sistem tangga nada diatonic atau disebut juga heptatonic, yang terdiri dari tujuh nada, yaitu do - re - mi - fa - so -la - si - do. Sebelumnya selama tiga ratus tahun di masa lampau, musik Barat menggunakan sistem tangga nada mayor dan minor (Hurd, 1989: 291; Malm, 1977: 119) .

22 Gereja Protestan Maluku, "Nyanyian Gereja Protestan Maluku” (Indonesia, 2011). 
Para komponis dari semua lagu yang terdapat pada buku Nyanyian jemaat telah memperkaya bentuk-bentuk alur melodi karya ciptanya secara unik dan menarik dengan sentuhan estetik pada semua jenis tangga nada, agar lagu-lagu tersebut dapat dinyanyikan dengan baik. Nyanyian Jemaat GPM juga mengandung muatan teologi musik gerejawi. Muatan teologi itu merupakan pesan dan isi teologi nyanyian jemaat yang kontekstual, musical Kristiani dan kultural. Lirik Nyanyian digubah dalam empat jenis Bahasa. Bahasa Indonesia, Melayu Ambon (contoh lagu nomor 148, 157, 210), Bahasa daerah di Maluku (contoh lagu nomor 7, 19, 27, 119, 141, 193, 214, 308, 326, 331, dl1), serta Bahasa tradisional gerejawo, yaitu Bahasa Ibrani (contoh lagu nomor 225, 226, 333, dll), dan Bahasa Yunani (contoh lagu nomor 55). Ini mencerminkan bahwa buku Nyanyian Jemaat adalah buku nyanyian yang kontekstual, bernuansa kearifan budaya lokal, oikumenis, tradisional gerejawi, dan nasional. ${ }^{23}$

Secara musikal, semua nyanyian dalam buku Nyanyian Jemaat menggunakan jenisjenis tangga nada yang bervariasi. Tangga nada pentatonic (memakai 5 nada), contoh: lagu nomor 60, 156, 121. Tangga nada tetratonis (memakai 4 nada), contoh lagu nomor 117, 147. Tangga Nada tritonis (memakai 3 nada), contoh lagu nomor 49, 285. Tangga nada sektetonis (memakai 6 nada), contoh lagu 59, 256. Tangga nada diatonic (memakai 7 nada) yang umumnya dipakai secara internasional. Ada juga nada-nada bernuansa khas Maluku, seperti pada lagu nomor 15, 41, 71, 280. Dalam analisis ini, Nyanyian GPM No.15 digunakan sebagai salah satu contoh untuk menunjukkan korelasi budaya, teologi, dan musik dalam Nyanyian GPM.

\section{MAE O, BASUDARA E}

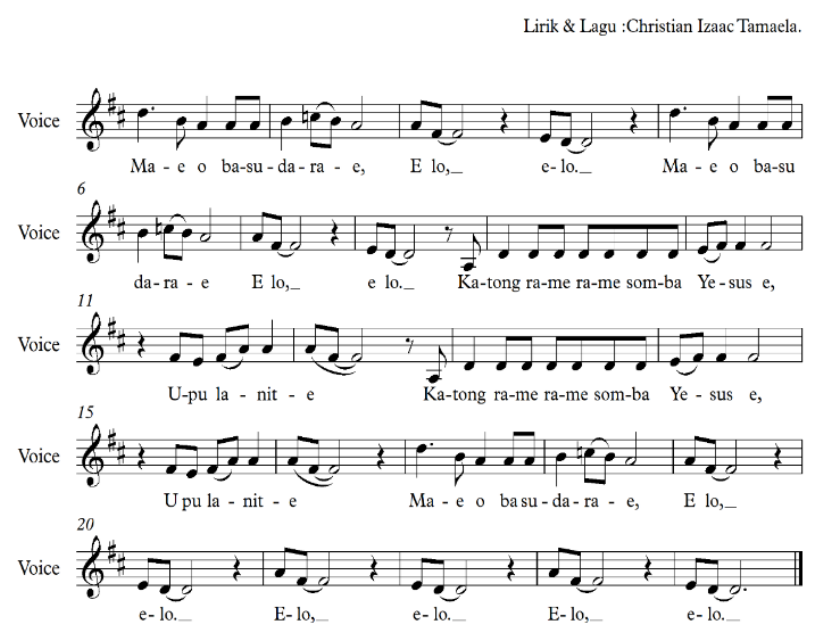

Gambar 1: Nyanyian GPM No.15

Terjemahan Nyanyian GPM. No. 15

Solo/PS: Mari oh mari, saudara-saudari; Jemaat: amin, amin...

Semua: Kita bersama-sama menyembah Tuhan Yesus, Tuhan Semesta langit Semua: Kita bersama-sama menyembah Tuhan Yesus, Tuhan Semesta langit Solo/PS: Mari oh mari, saudara-saudari; Jemaat: amin, amin.

${ }^{23}$ Ibid. 
Kekhasan dari lagu Maluku di sini terlihat dari pembawaan lagu tersebut, yang dinyanyikan secara responsoris atau berbalasan antara solo/paduan sura dengan jemaat. Pembawaan seperti ini menggambarkan nuansa lagu tradisional masyarakat Maluku Tengah, yang saling sahut-menyahut dalam aktivitas setiap hari seperti pada saat mereka sedang berada di hutan, di lautan atau saat mereka hendak melakukan kegiatan bekerja bersama (masohi). Ungkapan Mae o (Marilah), yang dibalas dengan elo (Ia, benar, atau amin) bernunjuk pada tindakan saling megajak seorang dengan yang lain atau mengajak semua orang untuk melakukan sesuatu hal secara bersama-sama. Dalam lagu ini, semua orang disapa dengan ungkapan kultural sebagai basudara e.

Menurut Watloly, ungkapan basudara e menunjuk pada hidup orang basudara, yakni suatu cara hidup yang menempatkan diri sesama anak negeri Maluku baik yang berbeda pulau, bahasa maupun agama di dalam sebuah keutamaan hidup sebagai saudara sekandung dari bumi Maluku untuk hidup saling peduli - baku kalesang, saling mengasihi - baku sayang, saling berdamai - baku bae. ${ }^{24}$ Dahulu sebelum menjadi masyarakat Maluku, penduduk yang tersebar di berbagai wilayah kepulauan Maluku masih menjadi kelompokkelompok yang terpisah di wilayahnya masing-masing. Mereka dikenal sebagai Orang Seram, Orang Kei, Orang Buru, Orang Yamdena, Orang Ambon, Orang Saparua, Orang Leti, dan sebagainya. Masing-masing kelompok masyarakat hidup dengan tradisi, adat, dan kepercayaannya. Mereka hidup dalam sikap eksklusif kelompoknya masing-masing, dan selalu ada rasa prasangka atau curiga, dendam hingga menimbulkan konflik atau pertikaian di antara masing-masing kelompok. Namun, seiring dengan adanya kesadaran untuk hidup bersama secara damai, aman dan nyaman di wilayah pulau-pulau yang terhubung oleh laut, maka terbentuklah suatu identitas bersama yang kemudian dikenali dengan sebutan orang Maluku sebagai orang basudara. ${ }^{25}$

Menurut Leonard Y. Andaya, konsep orang basudara mengakar pada kepercayaan asli masyarakat Maluku, bahwa semua orang di Maluku merupakan satu kesatuan mistis yang disebut Maluku yang menghubungkan seluruh pulau dengan keragaman etnolinguistik di dalamnya sebagai satu keluarga. ${ }^{26}$ Mengenai kepercayaan asli masyarakat Maluku, M. Huliselan, menyebutkan bahwa masih terekam dalam mitologi kepercayaan asli masyarakat Maluku narasi penciptaan bumi oleh adanya penyatuan Upu Lanite atau Tuhan langit atau Bapak Langit yang dipersonifikasi sebagai laki-laki dengan Ina ume atau Ibu bumi, yang dipersonifikasi sebagai perempuan. Penyatuan itu melahirkan manusia pertama laki-laki dan perempuan, yang diikuti dengan munculnya alam semesta. Dalam proses kontekstualisasi teologis, kepercayaan asli ini dihubungkan dengan keyakinan Kristen bahwa Tuhan Allah adalah pencipta langit dan bumi. Tuhan Allah adalah Upu lanite, yang berkuasa atas alam semesta yang diciptakan-Nya. Oleh karena itu, masyarakat Maluku yang beragama Kristen diajarkan untuk menyembah Tuhan Allah, Upu Lanite yang menyata di dalam Yesus Kristus,

\footnotetext{
${ }^{24}$ A Watloly, "Memperkuat Falsafah Hidop Orang Basudara," in Belayar Dalam Ombak, Berkarya Bagi Negeri: Pemeikiran Anak Negeri Maluku, ed. A Wakano (Ambon: Ralahalu Institute, 2012), 241.

${ }^{25}$ Ibid., 247.

${ }^{26}$ Leonard Y Andaya, Dunia Maluku: Indonesia Timur Pada Zaman Modern Awal (Yogyakarta: Penerbit Ombak, 2015), 1.
} 
penyelamat langit dan bumi serta isinya. Hal ini yang terungkap di dalam Nyanyian GPM No. 15 di atas. Dengan demikian, dalam nyanyian gereja, terutama gereja-gereja yang mempunyai basis kultural yang kuat, seperti Gereja Protestan Maluku, proses perpaduan budaya, teologi, dan musik di dalam nyanyian gereja, tidak dapat dihindari.

\section{Etnoteomusikologi Nyanyian GPM dalam Perpsektif Komunitasnya}

Selain interpretasi terhadap unsur etnik, teologi dan musik yang terdapat di dalam nyanyian GPM, analisis kualitatif berbasis seni juga dimaksudkan untuk menemukan persepsi dan makna karya seni bagi komunitas pemiliknya. Dalam hal ini, komunitas yang dimaksudkan adalah para komposer yang telah menciptakan lagu-lagu dalam nyanyian GPM, para pendeta, pemain musik, dan warga jemaat GPM, sebagai pengguna musik nyanyian GPM. Dari persepsi para informan inilah, ditemukan makna pentingnya etnoteomusikologi dari nyanyian GPM.

Bartje Istia, seorang komposer dari 38 lagu dalam Nyanyian Jemaat GPM, menjelaskan bahwa kesadaran kontekstual dalam menciptakan lagu-lagu yang mengakar pada rajutan nilainilai teologi, budaya, dan lingkungan hidup keseharian masyarakat Maluku, telah menjadi salah satu penciri dari Nyanyian Jemaat GPM. Walau demikian, menurut Istia, tidaklah mudah dalam menciptakan sebuah lagu, yang mengabungkan identitas budaya dari seluruh pulau di Maluku. Masyarakat Maluku sendiri memiliki karakteristik dan praksis budaya yang sangat beragam. Namun, nilai budaya hidop orang basudara dapat menjadi salah satu penanda identitas budaya bersama semua orang Maluku. ${ }^{27}$. Pandangan Istia ini menegaskan apa yang diungkapkan oleh Paul Gilbert, sebagai shared identity. Proses berbagi identitas terjadi di dalam konteks komunitas yang majemuk, dan mencari serta menemukan suatu ungkapan imaginasi dan simbolisasi kultural atau sejarah budaya, yang menjadi penghubung identitas-indentitas individu, atau partikular yang beragam. ${ }^{28}$

Melvy Alfons, komposer tiga lagu dalam Nyanyian GPM (No. 3, 47, 311), menyebutkan bahwa keterjalinan antara unsur teologi, budaya dan musik merupakan bentuk dari kontekstualisasi musik GPM. ${ }^{29}$. Pendeta Glen Viktor Hendriks yang menciptakan lima lagu dalam Nyanyian GPM, menjelaskan bahwa sebutan Nyanyian GPM, menandaskan bahwa musik (atau nyanyian) benar-benar mengakar dalam konteks hidup jemaat di Gereja Prostestan Maluku. Konteks hidup Gereja adalah konteks teologi, konteks sosial-budaya, dan konteks musikal. ${ }^{30}$ Rony Loppies, direktur Ambon Music Office (AMO), yang juga seorang musisi sekaligus warga jemaat GPM mengungkapkan bahwa melalui nyanyian-nyanyian Jemaat GPM, masyarakat Maluku sangat mudah menangkap pesan-pesan teologis yang disampaikan melalui musik, karena pesan itu dirajut di dalam bahasa musik, melodi dan syair yang mengakar kuat dalam tradisi kehidupan masyarakat Maluku. ${ }^{31}$

Edgard de Lima, komposer tujuh lagu dalam Nyanyian GPM menjelaskan bahwa keterhubungan unsur musik, budaya, dan teologi dalam Nyanyian Jemaat GPM bukan suatu kebetulan, tetapi karena ragam musik seperti itu telah menjadi karakter dari lagu-lagu gereja

\footnotetext{
${ }^{27}$ Bartje Istia (Komposer), wawancara, 03-12-2020.

${ }^{28}$ Paul Gilbert, Cultural Identity and Political Ethics, Cultural Identity and Political Ethics, 2010.

${ }^{29}$ Melvy Alfons (Komposer), wawancara, 14-10-2020.

${ }^{30}$ Glen Victor Hendriks (Pendeta/Komposer), Wawancara, 01-11-2020.

${ }^{31}$ Ronny Lopies (Direktur AMO), Wawancara, 14-10-2020.
} 
di Maluku. Lagu-lagu itu diciptakan dengan beberapa rasa yang tercampur, seperti rasa musikal, rasa budaya, realitas sosial, dan pengalaman hidup setiap hari. Ini yang menyebabkan Nyanyian Jemaat GPM menjadi dekat dan mudah dipahami oleh warga jemaat GPM. ${ }^{32}$

Pendeta Gamaliel Wirta, yang melayani di kepulauan Aru menyebutkan bahwa dalam pelayanan Ibadah Minggu, telah disepakati bahwa Nyanyian GPM selalu digunakan pada minggu terakhir bulan berjalan, bersamaan dengan pelaksanaan Ibadah bernuansa etnik Maluku. Namun, dalam peribadahan kategorial setiap hari, umat selalu menggunakan nyanyian-nyanyian dari Buku Nyanyian Jemaat GPM. Hal ini menurut Wirta, karena banyak lagu-lagu dalam Nyanyian Jemaat GPM, memiliki ungkapan-ungkapan yang sangat dekat dan menyentuh pengalaman hidup jemaat-jemaat. ${ }^{33}$ (Wirta, wawancara, 08-11-2020).

Pendeta Hein Tualena, yang melayani di Klasis Seram Utara, menyebutkan bahwa di Jemaat Maneo, tempatnya melayani, Nyanyian Jemaat GPM digunakan hampir setiap minggu secara bervariasi dengan Nyanyian Jemaat lainnya. Jemaat-jemaat sangat suka menyanyikan lagu-lagu di dalam nyanyian GPM dengan iringan alat musik tradisional seperti suling bamboo, ukulele, dan tifa. Suasana ibadah menjadi sangat kreatif, dan jemaat-jemaat dapat menjalani ibadah, memuji Tuhan dengan penuh sukacita dan ungkapan syukur. ${ }^{34}$ Hal yang sama diungkapan oleh Ema Kwalomine, dan Petra Manuhua, yang biasanya berperan melatih kelompok pengiring musik dan singer di jemaat-jemaat. Menurut Kwalomine, Nyanyian Jemaat GPM mudah dipahami dan dibawakan karena simplisitas atau kesederhanan dari lagulagu yang ada. Ketika lagu-lagu itu dilatih untuk dinyanyikan oleh Jemaat, sangat mudah mereka mengikutinya. ${ }^{35}$ Menurut Manuhua, lagu-lagu dalam Nyanyian Jemaat GPM, tidak hanya menggunakan bahasa budaya, tetapi juga melodi dan unsur-unsur musik yang begitu melekat dalam kebiasaan bernyanyi masyarakat Maluku. ${ }^{36}$ Leonora Pessiwarisa, seorang anggota Jemaat, menyebutkan bahwa lagu-lagu Nyanyian Jemaat ini tidak hanya dinyanyikan di dalam ruang Ibadah, tetapi mengikuti kebiasaan masyarakat Maluku yang suka bernyanyi, maka lagu-lagu ini pun bisa didengar dan dijumpai di dalam ruang aktivitas masyarakat, di pasar, di hutan, di kebun, hingga di dalam kendaran-kendaran umum. ${ }^{37}$

Dari pendapat para informan di atas, saya menemukan dua dimensi utama dalam interelasi teologi, budaya, dan musik, dalam Nyanyian Jemaat GPM. Pertama, Nyanyian Jemaat GPM telah menjadi bagian dari eksistensi musik lokal Maluku, atau meminjam ungkapan Tamaela, bahwa musik telah mengalami kontekstualisasi atau supuasi musik dan liturgi. ${ }^{38}$ Kedua, dalam analisis-analisis etnoteomosikologi, saya menemukan bahwa musik mempunyai kekuatan asosiatif, yang dapat menghubungkan rasa musikal dengan pengalaman dan konteks hidup manusia atau komunitas pemilik musik tersebut, baik pengalaman teologis, maupun konteks sosial budaya. Dalam kaitan itu, Gereja perlu terus menggali kekayaan

\footnotetext{
${ }^{32}$ Edgard j. de Lima (composer), Wawancara, 14 -10-2020.

${ }^{33}$ Gamaliel Wirta (Pendeta GPM), Wawancara, 08-11-2020.

${ }^{34}$ Hein Tualena (Pendeta GPM), Wawancara, 07-11-2020.

${ }^{35}$ Ema Kwalomine (Pelatih Musik di Jemaat), Wawancara, 14-10-2020.

${ }^{36}$ Petra Manuhua (Pelatih Musik di Jemaat GPM), Wawancara, 14-10-2020.

${ }^{37}$ Leonora Pesiwarissa (Warga Jemaat, Dosen Sastra di UNPATTI, Ambon), Wawancara, 15-10-2020.

${ }^{38}$ Christian Izaac Tamaela, "Contextualization of Music and Liturgy in the Moluccan Church." 167.
} 
unsur-unsur budaya yang dapat merepresentasi seluruh wilayah pelayanan di Maluku, untuk mengembangkan nyanyian GPM. Selanjutnya, Gereja juga perlu mensosialisasi pentingnya perpaduan unsur-unsur etnik, teologi dan musik dalam nyanyian GPM bagi warga gerejanya agar makin memahami makna identitas kekristenannya di dalam konteks lokal masyarakat Maluku melalui musik atau nyanyian GPM.

Christian Izaak Tamaela menyebutkan bahwa kontekstualisasi musik dan liturgi di Maluku mengakar pada beberapa unsur penting. Pertama, basis dari kontekstualisasi musik dan liturgi di Maluku adalah inkarnasi Allah di dalam Yesus Kristus. Doktrin teologis tentang Allah yang berinkarnasi di dalam kemanusiaan Yesus Kristus, menjadi sebuah contoh bagaimana musik itu juga haruslah berinkarnasi di dalam pengalaman manusia dan konteks sosialkebudayaannya. Kedua, Yesus Kristus adalah anak Allah sekaligus Anak Manusia yang hidup di dunia, dan mengalami seluruh kenyataan sosial-budaya yang ada di sekitarnya. Yesus mengajar mengenai roti hidup, air hidup, pohon arah, gembala yang baik, dan berbagai ekspresi simbolik yang diambil dari konteks dan kebiasaan kultural masyarakat. Itu artinya, dalam kontekstualisasi musik, bukan suatu hal yang dilarang, jika Nyanyian-nyanyian Jemaat menggunakan ungkapan-ungkapan dalam kultur dan pengalaman hidup masyarakat. Ketiga, dalam Alkitab kita juga selalu menjumpai ungkapan-ungkapan yang berkaitan dengan keberadaan para leluhur, seperti Allah Abraham, Izaak, dan Yakub. Musik lokal Maluku juga mempunyai koneksi dengan keberadaan para leluhur, yang dihormati, dan tidak disembah. Karena itu, ekspresi budaya seperti orang basudara, Pela-gandong, Ain ni Ain, Kalwedo, mae $o$, elo yang sesungguhnya adalah warisan para leluhur juga dapat digunakan untuk memuliakan Allah. ${ }^{39}$

Dalam analisis musikologi, musik memiliki kekuatan asosiatif yang dapat menghubungkan seseorang dengan konteks tertentu. Ketika seorang Maluku yang berada di tanah rantau mendengarkan nyanyian gandong, maka serentak orang tersebut dapat bernyanyi, dan bisa saja menetes air matanya. Namun, ketika seorang Maluku mendengarkan gending Solo, atau musik Bali, maka perasaan biasa saja, atau bahkan tidak dihiraukan sama sekali keberadaan musik tersebut. Dalam salah satu analisis, saya menemukan itu dalam fungsi musik untuk menjadi salah satu media rekonsiliasi. Jacky Manuputty menceritakan pengalaman memediasi konflik dan membangun perjumpaan antara dua komunitas di Bali pada tahun 2000. Ketika dua komunitas Muslim dan Kristen berjumpa di ruang perundingan, yang terjadi adalah mereka saling melempar dengan kursi. Panitia kemudian memutarkan alunan musik Bali, namun tidak berpengaruh. Manuputty, spontan menyanyikan lagu gandong, serentak yang ada adalah air mata yang menetes, dan mereka kemudian saling memeluk seorang dengan yang lainnya. Ini adalah salah satu contoh kekuatan asosiatif musik. ${ }^{40}$ Para informan di atas juga menyebutkan bahwa Nyanyian Jemaat GPM, sangat mudah dipahami, sangat mudah dinyanyikan, bukan hanya di Gedung gereja, tetapi juga di ruang-ruang kehidupan. Bagi saya, Nyanyian Jemaat GPM, memiliki kekuatan asosiatif, yang mampu menghubungkan pengalaman musikal, dengan pengalaman budaya, sosial, dan pengalaman

\footnotetext{
${ }^{39}$ Ibid., 168,169.

${ }^{40}$ Lestari, "Peran Musik Sebagai Salah Satu Media Perdamaian."
} 
hidup jemaat setiap hari. Dengan demikian, menurut saya, etnoteomusikologi bukan hanya suatu bentuk musik yang kontekstual, tetapi juga musik yang asosiatif.

\section{Kesimpulan}

Di dalam nyanyian GPM, ditemukan perpaduan harmonis antara unsur-unsur budaya Maluku dengan ajaran dan pendangan teologis yang terajut di dalam unsur-unsur musik liturgis dari setiap lagu. Unsur-unsur budaya itu berupa tata nilai dan pandangan hidup, ungkapan leksionaris budaya Maluku seperti orang basudara, mae o, elo, upu lanite, pela-gandong, dan berbagai bahasa yang termuat dalam teks lagu, juga terekspresikan di dalam nada, melodi, ritme musikal. Perpaduan unsur-unsur budaya, teologis dan musik memiliki peranan dan fungsi, tidak sebatas untuk menjadi suatu ekpresi memuliakan Tuhan di dalam peribadahan, tetapi juga melekat fungsi membangun identitas budaya dan identitas kekristenan bagi masyarakat pemilik musik tersebut.

Dari hasil penelitian ini, saya menemukan dua dimensi utama dalam interelasi teologi, budaya, dan musik, dalam Nyanyian Jemaat GPM. Pertama, Nyanyian Jemaat GPM telah menjadi bagian dari eksistensi musik lokal Maluku, atau meminjam ungkapan Tamaela, bahwa musik telah mengalami kontekstualisasi atau supuasi musik dan liturgi. Kedua, dalam analisis etnomosikologi dan teomusikologi, ditenemukan bahwa musik mempunyai kekuatan asosiatif, yang dapat menghubungkan rasa musikal dengan pengalaman dan konteks hidup manusia atau komunitas pemilik musik tersebut, baik pengalaman teologis, maupun konteks sosial budaya. Melalui kandungan etnotheomusikologis dalam Nyanyian Gereja, maka umat tidak sebatas memuliakan Allah tetapi bersamaan dengan itu mengalami kehadiran Allah di dalam pengalaman sosial-budayanya yang diekspresikan melalui musik. Itulah etnotheomusikologis. Kajian ini dapat dikatakan sebagai sebuah sketsa awal memperkenalkan pendekatan studi etnoteomusikologis, karenanya, bagi penelitian selanjutnya, direkomendasikan untuk dapat mengembangkan sebuah piranti analisis etnoteomusikologis di dalam sebuah analisis musik gereja.

\section{Referensi}

Andaya, Leonard Y. Dunia Maluku: Indonesia Timur Pada Zaman Modern Awal. Yogyakarta: Penerbit Ombak, 2015.

Bramantyo, Triyono. Desiminasi Musik Barat Di Timur. Yogyakarta: Yayasan Untuk Indonesia, 2004.

Christian Izaac Tamaela. "Contextualization of Music and Liturgy in the Moluccan Church." Vrije Universiteit, Amsterdam, 2015.

Finley, Susan. "Penelitian Berbasis Seni: Mementaskan Pedagogi Revolusioner." In The Sage of Qualitative Research 2, edited by Norman K Denzin and Yvnonna S Linncoln. 3rd ed. Yogyakarta: Pustaka Pelajar, 2011.

Gaspersz, Agustinus S.W. Sejarah Penyebaran Nyanyian Gereja Oleh Misionaris Belanda Di Maluku. Yogyakarta: TICI Publication, 2013.

Gereja Protestan Maluku. "Nyanyian Gereja Protestan Maluku.” Indonesia, 2011.

Gilbert, Paul. Cultural Identity and Political Ethics. Cultural Identity and Political Ethics, 2010.

Hastanto, Sri. Konsep Pathet Dalam Karawitan Jawa. Surakarta: Program Pascasarjana dan ISI Press Surakarta, 2009. 
Heaney, Maeve Louise. "Music and Theological Method: A Lonerganian Approach." Theological Studies 77, no. 3 (September 2016): 678-703. http://tsj.sagepub.com/ (Subscriber access).

Latupapua, Falantina Ery, Martha Maspaitella, Everhard Markiano Solissa, Grace Somelok, and Heppy Leunard Lelapary. Kapata: Sastra Lisan Di Maluku. Ambon: Balai Pengkajian Nilai Budaya Provinsi Maluku dan Maluku Utara, 2012.

Lensink, Jip. "Traditional Tunes Transformed: Resonance and Dissonances Between Theology and Lived Religion in The Protestant Church on the Central Moluccas." Utrecht University, n.d.

Lestari, Dewi Tika. "Membangun Harmoni Sosial Melalui Musik Dalam Ekspresi Budaya Orang Basudara Di Maluku.” Panggung (2020). . "Peran Musik Sebagai Salah Satu Media Perdamaian.” Institut Seni Indonesia (ISI) Surakarta, 2017.

- "Religious Conflict Transformation through Collective Memory and the Role of Local Music," 2019.

Lestari, Dewi Tika, and Yohanes Parihala. "Teologi, Musik, Dan Perdamaian: Visi Teologi Lukas 12: 51-53 Dan Analisis Musik Ode Buat Maluku.” DUNAMIS: Jurnal Teologi dan Pendidikan Kristiani (2020).

Nakagawa, Shin. Musik Dan Kosmos: Sebuah Pengantar Etnomusikologis. Jakarta: Yayasan Obor Indonesia, 2000.

Osbeck, Kenneth W. The Ministry of Music. Grand Rapids: Kregel Publication, 2010.

Prier, Karl Edmund, and Paul Widyawan. Roda Musik Liturgi : Panduan Untuk Para Petugas Musik Liturgi. Yogyakarta: Pusat Musik Liturgi, 2011.

Sugiyono. Metode Penelitian Dan Pengembangan (Research and Development/R\&D). Bandung: Alfabeta, 2016.

Watloly, A. "Memperkuat Falsafah Hidop Orang Basudara." In Belayar Dalam Ombak, Berkarya Bagi Negeri: Pemeikiran Anak Negeri Maluku, edited by A Wakano. Ambon: Ralahalu Institute, 2012. 